\title{
RANCANGAN APLIKASI PENDATAAN DAN PELAYANAN PASIEN DI KLINIK CIREUNDEU MEDIKA
}

\author{
Telly Septiono ${ }^{1}$, Ari Irawan ${ }^{2}$ \\ ${ }^{1,2}$ Teknik Informatika, Fakultas Teknik dan Ilmu Komputer, Universitas Indraprasta PGRI Jakarta \\ Jalan Raya Tengah No 80, Kelurahan Gedong, Pasar Rebo, Jakarta Timur \\ $\underline{1 \text { theosepti265@gmail.com, }}{ }^{2}$ ari.irawan69@gmail.com
}

\begin{abstract}
ABSTRAK
Pendataan serta pelayanan pasien di Klinik Cireundeu Medika masih dicatat dengan menggunakan media kertas dan sering sekali terjadi kesalahan. Tujuan merancang suatu sistem informasi pendataan dan pelayanan pasien dengan tujuan untuk memproses pengolahan data pelayanan pasien yang ada saat ini. Perangkat aplikasi yang telah dibuat dengan bahasa pemrograman Java NetBeans 8.0.2 dan penyimpanan data pada database MySQL dapat memberikan kelancaran dalam proses menginput dan penyimpanan data-data serta laporanlaporan yang diberikan kepada pimpinan klinik. Dengan menggunakan metode pengembangan sistem yaitu Waterfall dalam penelitian ini adalah dengan tahapan-tahapan seperti rekayasa sistem, analisis, desain, coding, testing, dan maintenance. Hasil dari penelitian ini menciptakan suatu sistem informasi pelayanan pasien yang dapat memudahkan bagian administrasi dalam proses pendataan data pasien, data pelayanan pasien sehingga proses pendataan penginputan data seta pelaporannya bisa lebih baik dan akurat.
\end{abstract}

Kata Kunci: Sistem Informasi, Pelayanan, Pasien, Java

\begin{abstract}
Data collection and patient services at the Cireundeu Medika Clinic are still recorded using paper media, and errors often occur. The purpose of designing an information system for data collection and patient services with the aim of processing data processing for existing patient services. Application tools that have been created with the Java NetBeans 8.0.2 programming language and data storage in the MySQL database can provide smooth processing of input and storage of data and reports given to clinic leaders. Using the system development method, namely Waterfall, in this research, the stages are systems engineering, analysis, design, coding, testing, and maintenance. The results of this study create a patient service information system that can facilitate the administration in collecting patient data and patient service data so that the data collection process, input data, and reporting can be better and more accurate.
\end{abstract}

Key Word: Information System, Service, Patient, Java

\section{PENDAHULUAN}

Perkembangan teknologi komputer pada saat ini sudah banyak dibutuhkan penggunaannya karena dapat mempermudah dalam pengaksesan jaringan-jaringan yang dapat dilakukan untuk perpindahan dari sebuah data menjadi informasi. Kemampuan pada teknologi dapat mempermudah kita untuk lebih cepat mendapatkan data dan informasi. Komputer tidak hanya digunakan dalam bidang Perbankan, Transportasi, Pendidikan, Industri, tetapi juga dalam bidang Kesehatan. Dalam bidang Kesehatan komputer sangat dibutuhkan untuk menginput dan menyimpandata pasien (Utami, 2015).

Klinik Cireundeu Medika merupakan salah satu pelayanan publik yang membutuhkan komputer pada saat ini. Tidak hanya menginput dan menyimpan data pasien, komputer juga dapat mempermudah dalam pengolahan data pasien, penyimpanan hasil Rekam Medis pasien dan dalam membuat laporan (Syofian \& Widyantoro, 2018).

Klinik Cirendeu Medika merupakan sebuah Klinik yang berlokasi di Ciputat Timur, Tangerang Selatan, Banten, Indonesia. Saat ini, dokter-dokter yang melakukan praktek di Klinik Cirendeu Medika diantaranya adalah dr. Farah Khiyatie. Adapun beberapa layanan kesehatan yang dapat Anda temukan di Klinik Cirendeu Medika adalah Gigi, Laboratorium, Kedokteran Gigi Anak, Konservasi Gigi, Penyakit Dalam, dan Umum.

Klinik Cireundeu Medika saat ini masih menggunakan sistem manual baik dalam pelayanan dan pendataan pasien. Jumlah pasien yang berobat di Klinik Cireundeu Medika sampai saat ini sudah lebih dari 200 pasien jadi dapat dibayangkan berapa jumlah 
kartu berobat yang di simpan di Klinik Cireundeu Medika. Sedangkan ketika pasien berobat pasien hanya menyerahkan KTP dan bagian pendaftaran harus mencari kartu berobat pasien sesuai dengan nama pasien sesuai abjad atau sesuai dengan nama kepala keluarga satu-persatu. Hal inilah yang sering membuat lamanya pasien melakukan pendaftaran, jika nama pasien tidak ditemukan maka bagian pendaftaran akan membuat kartu baru dan akan terjadi penumpukkan jika terlalu sering dilakukan (Sofica, Agista, Ningsih, \& Septiani, 2019).

Menyatunya kartu berobat antara pasien lama dan pasien baru juga membuat bagian pendaftaran sedikit kesulitan terutama jika ada data atau kartu berobat pasien yang hilang karena jika kartu berobat pasien hilang maka hasil diagnosa atau pemeriksaan dokter selama pasien tersebut berobat juga akan hilang. Pembuatan laporan yang juga masih menggunakan sistem manual dengan cara mencatat di dalam pembukuan juga dapat mengakibatkan hilangnya laporan tersebut.

Dengan permasalahan tersebut, perlu adanya suatu sistem yang terkomputerisasi dalam penyelesaiannya. Sistem adalah sekelompok unsur yang erat hubungannya satu dengan yang lain, yang berfungsi bersama-sama untuk mencapai tujuan (Sutabri, 2012). Sistem merupakan suatu kumpulan dari komponenkomponen yang membentuk satu kesatuan (Tyoso, 2016). Pembangunan sistem adalah sekumpulan aktivitas yang menggambarkan secara rinci bagaimana sistem akan berjalan. Hal itu bertujuan untuk menghasilkan produk perangkat lunak yang sesuai dengan kebutuhan user (Satzinger, J. W., Jackson, R. B., Burd, n.d.).

Dengan adanya komputer diharapkan dapat membantu dalam pelayanan yang akan diberikan kepada pasien dengan begitu pelayanan yang diberikan dapat semaksimal mungkin (Fatkhudin \& Alifiani, 2017). Tujuan utama dari adanya Klinik Cireundeu Medika adalah menyediakan layanan kesehatan yang bermutu namun dengan biaya yang relatif terjangkau untuk masyarakat, terutama masyarakat dengan kelas ekonomi menengah ke bawah (Rahmat Tullah, 2019).
Diharapkan dengan adanya suatu sistem informasi dapat menangani permasalahan yang ada di perusahaan tersebut. Sistem adalah setiap sesuatu terdiri dari obyek-obyek, atau unsur-unsur, atau komponen-komponen yang bertata kaitan dan bertata hubungan satu sama lain, sedemikian rupa sehingga unsurunsur tersebut merupakan satu kesatuan pemrosesan atau pengolahan yang tertentu. (Prasojo, 2011)

Aplikasi ini lebih baik menggunakan bahasa pemrograman Java dengan editor Netbeans 8.0.2 yang lebih responsif sehingga dapat memudahkan pekerjaan Admin dalam melaksanakan proses penginputan data serta pembuatan laporan dan dapat memudahkan perusahaan dalam proses pendataan dan pelayanan pasien di Klinik Cireundeju Medika.

\section{METODE PENELITIAN}

Peneliti menggunakan metode Grounded Research dalam penyelesaian penelitian ini. (Sugiyono, 2016) Grounded Research adalah suatu metode yang berfokus kepada fakta serta menggunakan cara analisis yang menerapkan suatu konsep-konsep untuk membuktikan suatu teori dan dapat dikembangkan dalam proses pengolahan data analisis dalam waktu yang bersamaan. Tujuan dari metode grounded research ini mengadakan generalisasi empiris serta ditetapkannya suatu konsep dalam mencapai suatu teori sehingga dikembangkan. Penelitian juga bertujuan untuk menjabarkan suatu konsep, yang bisa diartikan mencerna beberapa contoh kasus sehingga dapat dibandingkan untuk beberapa kasus sebagai referensi. Perbandingan ini akan memaparkan suatu unsur-unsur baru yang dapat dipelajari.

\section{HASIL DAN PEMBAHASAN \\ Alternatif Penyelesaian Masalah}

Hasil dari pengembangan sistem pendataan dan pelayanan Klinik Cireundeu Medika ini adalah sistem yang dapat bekerja secara terkomputerisasi baik dalam pembuatan kartu berobat pasien, pendataan pasien ketika mendaftar, kunjungan pasien setiap waktunya, menyimpan hasil diagnosa dokter, menyimpan data obat yang keluar dan masuk secara rinci, dan dalam menyimpan laporan setiap minggunya, serta dalam pelayanan pun dapat menjadi lebih baik dan semaksimal 
mungkin. Dan membuat penyimpanan data atau Database agar data dapat lebih akurat serta dapat mengurangi kemungkinan kehilangan data.

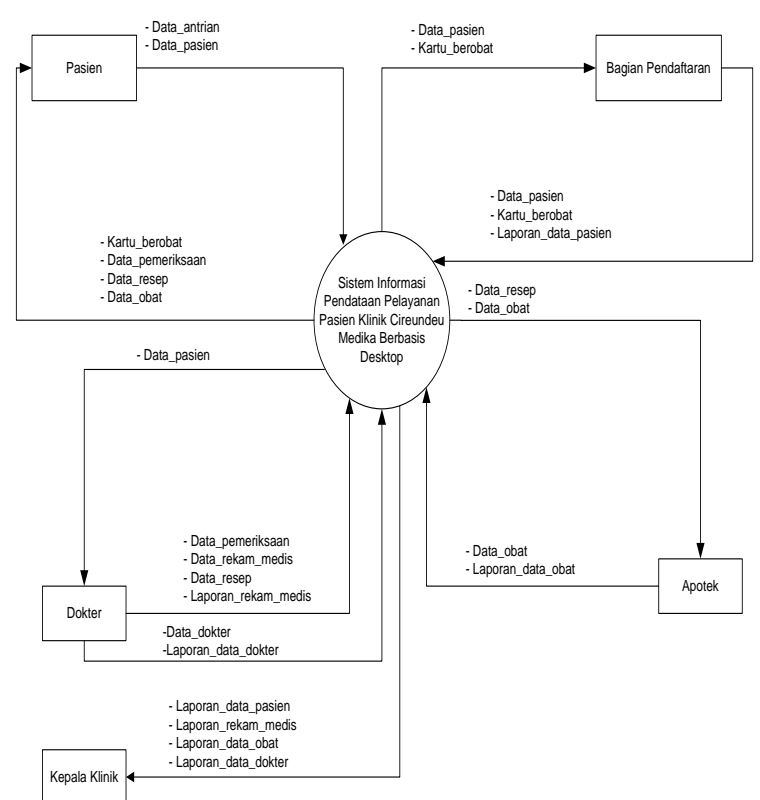

\section{Gambar 1. Diagram Konteks}

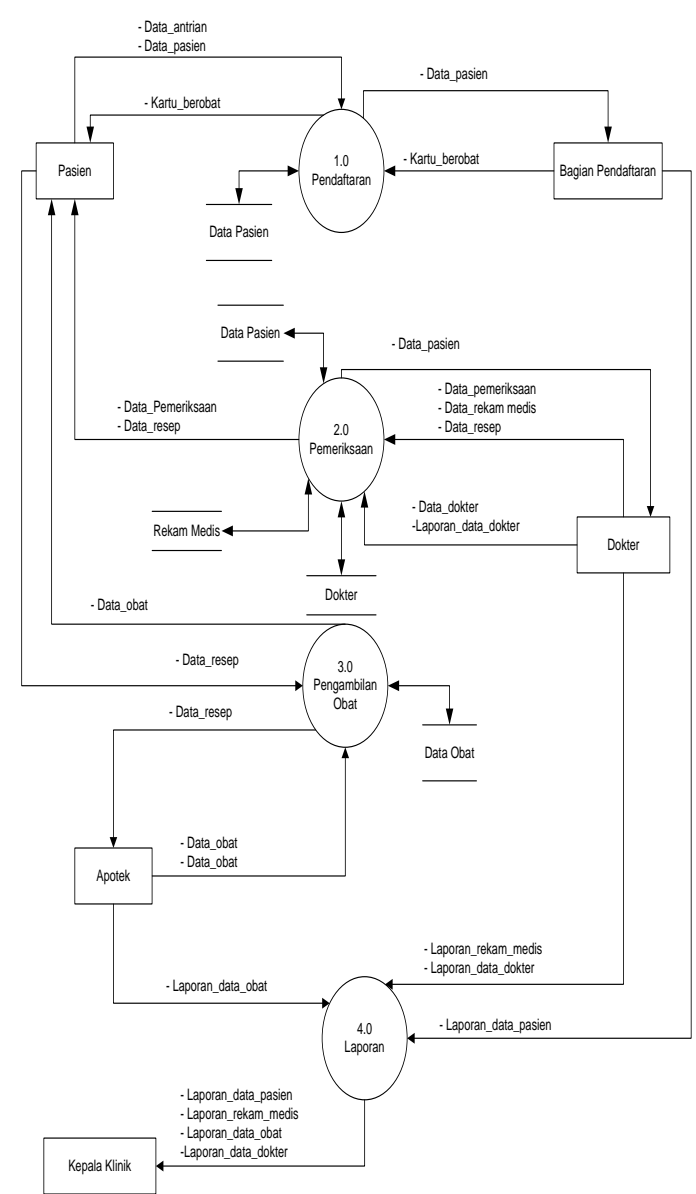

Gambar 2. Diagram Nol

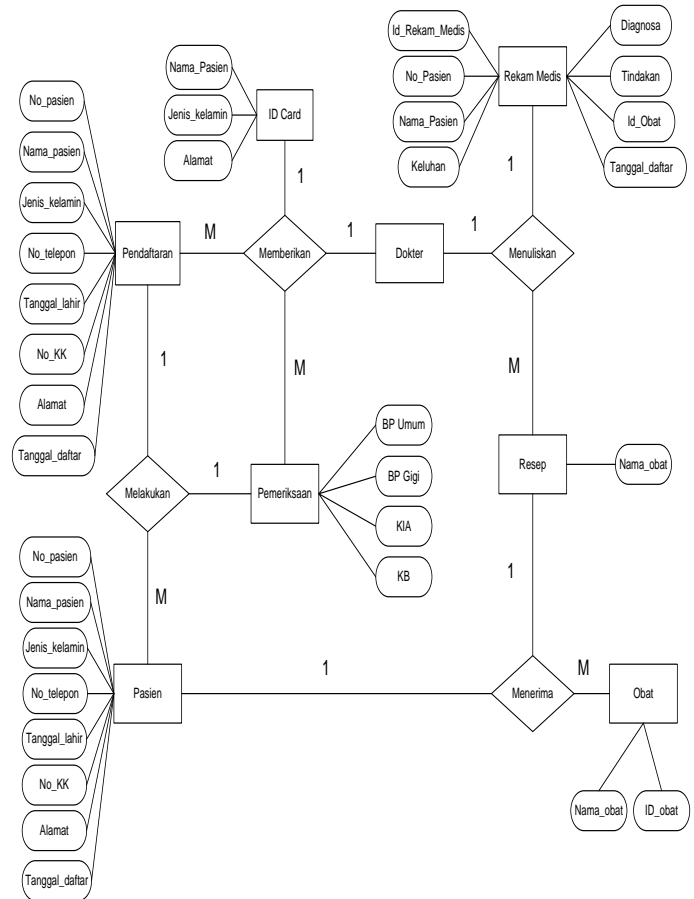

Gambar 3. ERD (Entity Relationship Diagram)

Berikut adalah tampilan layar dan hasil pengujian pada software program yang telah di buat dengan bahasa pemrograman Java.

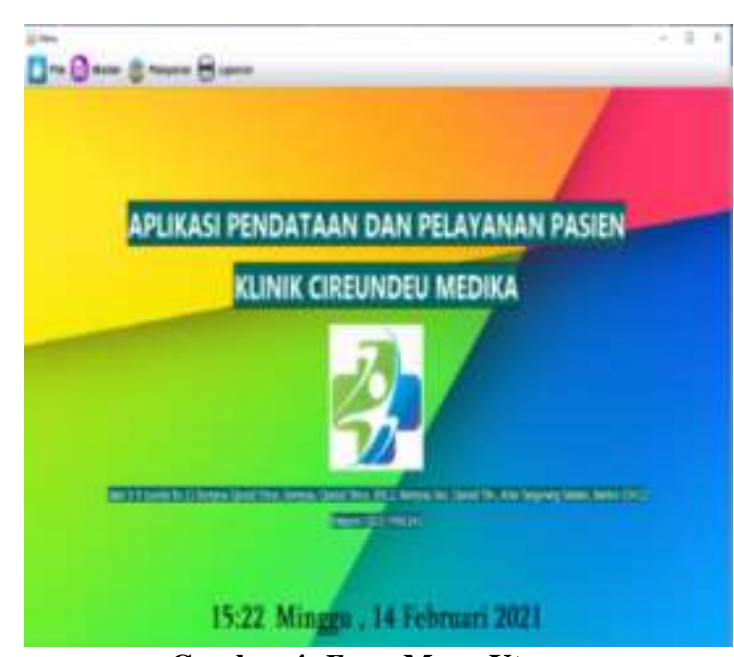

Gambar 4. Form Menu Utama

Layar di atas menampilkan tampilan Menu Utama pada Aplikasi Pendataan dan Pelayanan Pasien Klinik Cireundeu Medika. Pada layar utama tersedia menu bar yang terdiri dari master data yang digunakan untuk memasukkan data yang berkaitan dengan data pasien, data obat, data dokter, data pemeriksaan, data resep dan laporan-laporan. 


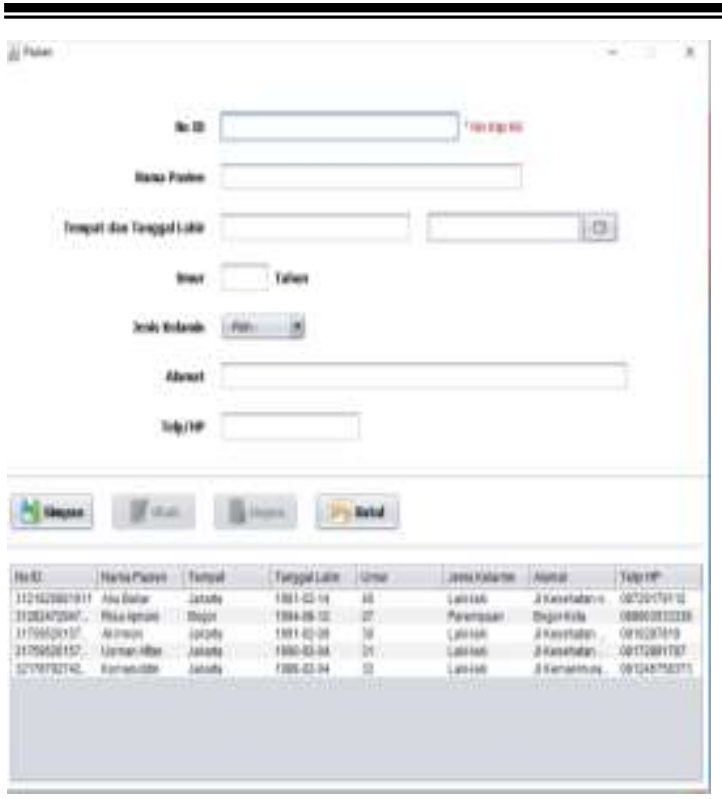

Gambar 5. Form Data Pasien

Layar di atas menampilkan tampilan form data pasien. Pada layar form data pasien untuk meng-input data pasien yang terdiri dari No ID, Nama Pasien, Tempat dan Tanggal Lahir, Umur, Jenis Kelamin, Alamat dan Telp/HP.

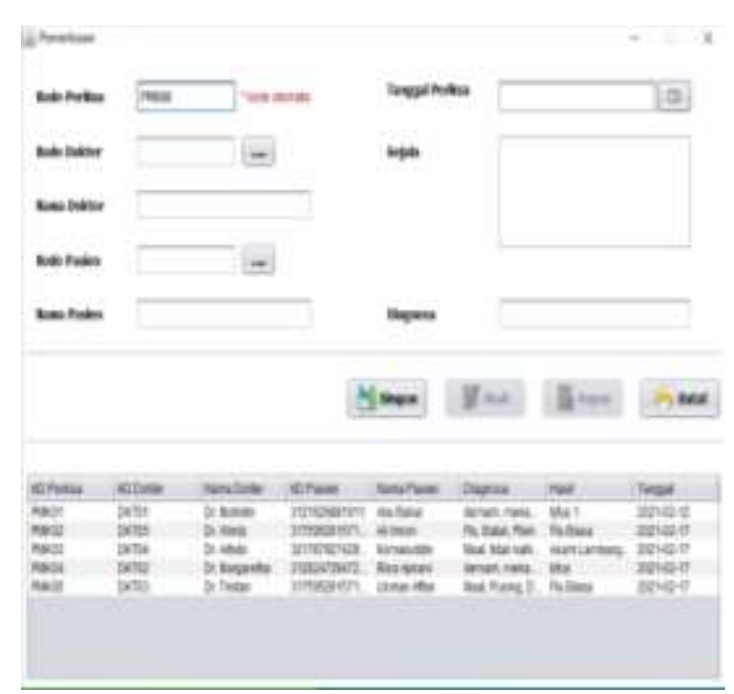

Gambar 6. Form Data Pemeriksaan

Layar di atas menampilkan tampilan form data pemeriksaan. Pada layar form data pemeriksaan untuk meng-input data pemeriksaan yang terdiri dari Kode Periksa, Kode Dokter, Nama Dokter, Kode Pasien, Nama Pasien, Tanggal Periksa, Gejala, dan Diagnosa.

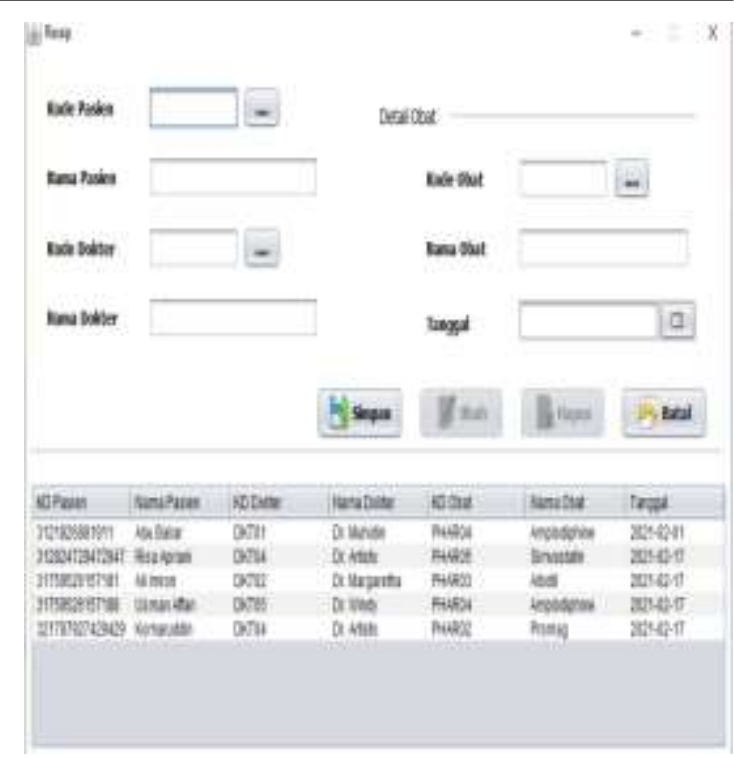

Gambar 7. Data Form Data Resep

Layar di atas menampilkan tampilan form data resep. Pada layar form data resep untuk menginput data resep yang terdiri dari Kode Pasien, Nama Pasien, Kode Dokter, Nama Dokter, Kode Obat, Nama Obat, dan Tanggal.

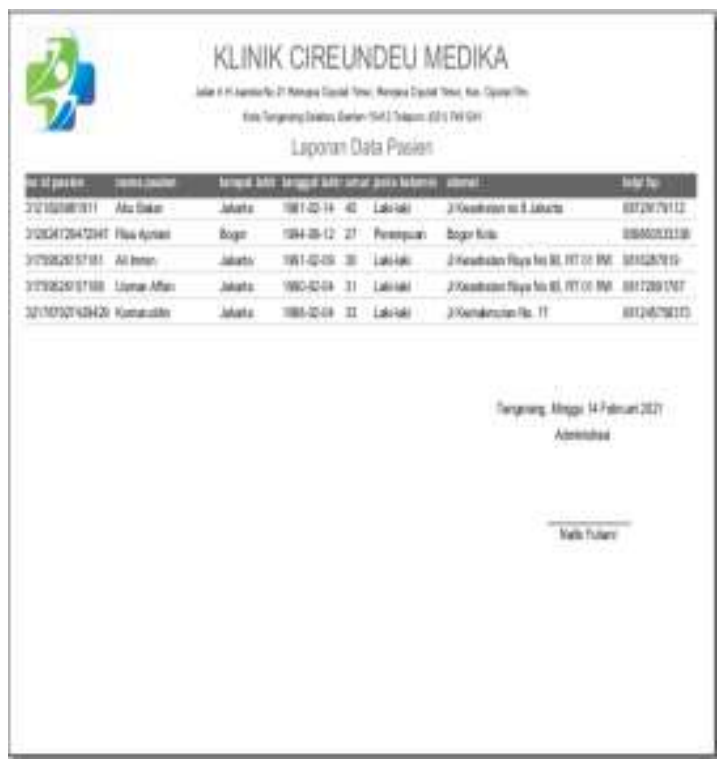

Gambar 8. Laporan Data Booking Mobil

Layar di atas menampilkan tampilan form laporan data pasien. Pada layar form data pasien digunakan untuk mengecek laporan data pasien terdiri No ID, Nama Pasien, Tempat dan Tanggal Lahir, Umur, Jenis Kelamin, Alamat dan Telp/HP. 


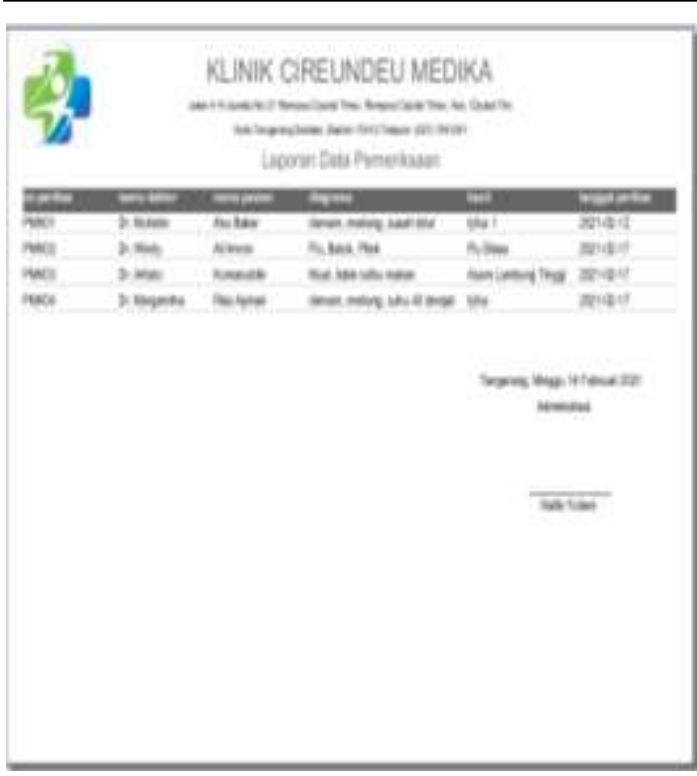

Gambar 9. Laporan Data Pemeriksaan

Layar di atas menampilkan tampilan form laporan data pemeriksaan. Pada layar form data pemeriksaan digunakan untuk mengecek laporan data pemeriksaaan terdiri No Periksa, Nama Dokter, Nama Pasien, Diagnosa, Hasil dan Tanggal Periksa.

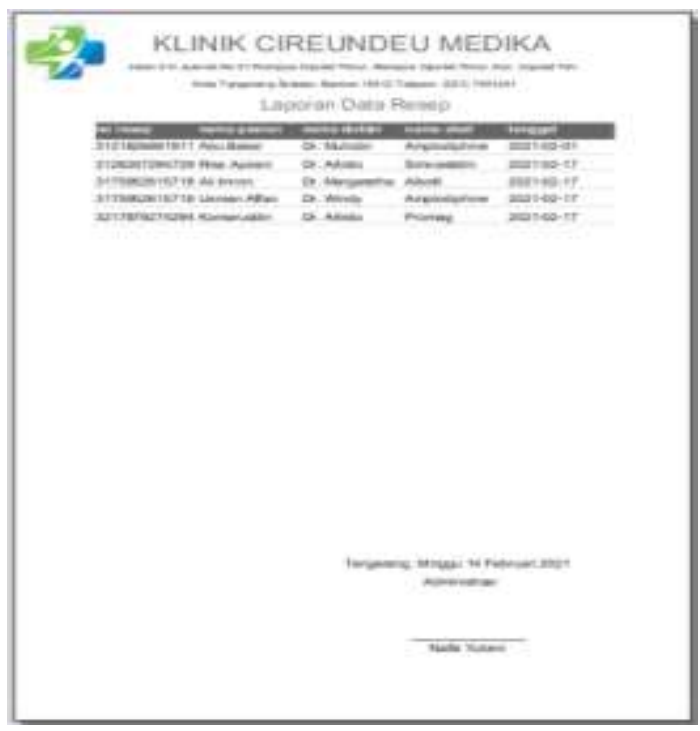

Gambar 10. Laporan Data Resep

Layar di atas menampilkan tampilan form laporan data resep. Pada layar form data resep digunakan untuk mengecek laporan data resep terdiri No Resep, Nama Pasien, Nama Dokter, Nama Obat dan Tanggal.

\section{SIMPULAN DAN SARAN}

Dengan menggunakan sistem komputerisasi maka Klinik Cireundeu Medika mengalami peningkatan dalam menangani proses seluruh data dibandingkan sistem manual. Pengolahan data pasien Klinik Cireundeu Medika lebih efektif, serta keamanan terhadap data lebih terjamin. Proses dalam pembuatan laporan dapat dilakukan dengan cepat dan akurat.

Saran dengan penggunaan sistem informasi pendataan dan pelayanan pasien ini bagi bagian pendaftaran pada klinik ada beberapa hal yang harus diperhatikan yaitu ketelitian dan kecermatan dibidang komputer harus diperhatikan dengan sungguh-sungguh dan diperlukan adanya tenaga ahli yang terampil, baik dalam mengoperasikan maupun pengontrolan software.

\section{DAFTAR PUSTAKA}

Fatkhudin, A., \& Alifiani, D. N. (2017). Sistem Informasi Pendaftaran Pasien Pada Klinik dr. Veri kajen Kabupaten Pekalongan Berbasis Android. Jurnal Ilmiah Edutic.

Prasojo, M. (2011). Pengantar Sistem Informasi Manajemen. bandung: CV. Remadja Karya.

Rahmat Tullah, A. A. (2019). Perancangan Sistem Informasi Data Pasien di Klinik Aulia Medika Pasarkemis. Sisfotek Global.

Satzinger, J. W., Jackson, R. B., Burd, S. D. (n.d.). System Analysis and Design in A Changing World. USA: Cengage Learning.

Sofica, V., Agista, S. T., Ningsih, R., \& Septiani, M. (2019). Aplikasi Pendaftaran Pasien Rawat Jalan Online pada Klinik Mulya Medika menggunakan Waterfall. Bianglala Informatika.

Sugiyono. (2016). Metode Penelitian Kuantitatif, Kualitatif dan $R \& D$. Bandung: PT Alfabet.

Sutabri, T. (2012). Analisis Sistem Informasi. Yogyakarta: Andi.

Syofian, S., \& Widyantoro, W. T. (2018). Sistem Informasi Pelayanan Pasien Rawat Jalan Menggunakan Aplikasi Pada Klinik Annisa Di Ciracas. Jurnal Teknologi Informasi.

Tyoso, J. S. P. (2016). Sistem Informasi Manajemen. Yogyakarta: DeePublish.

Utami, L. A. (2015). Sistem Informasi Administrasi Pasien Pada Klinik Keluarga Depok. Konferensi Nasional Ilmu Pengetahuan Dan Teknologi. 